\title{
O ACALANTO E O CLARIM \\ (LITERATURA, TIRANIA, EXPRESSÃO) \\ ENSAIO SOBRE A MULTIDÃO LITERÁRIA ${ }^{1}$ \\ Philippe Beck
}

* (Les Politiques, I, 2, 1252a. Tradução de Pierre Pellegrin Paris: Garnier-Flammarion, 1990: 90.)

* (NIETZSCHE, F. Par-delà le bien et le mal (1886), III, § 62.)
Adição, multiplicação, divisão. Infinita literatura e transdução. História de lobos. O lamento combativo. Pacto do irmão hipócrita. A exceção.

Um homem é uma impossibilidade dourada.

(Emerson)

É impossível encontrar reconforto em um pessimismo profético. (T. S. Eliot)

Talvez haja pessoas que precisem pensar no Estado até durante o sono, mas na realidade nunca ninguém pensou em apenas uma coisa sem interrupção. (Sôseki)

Uma luta feroz acontece entre os homens. Bem. A constatação é antiga e traçada em todas as línguas europeias. Em $A$ Comédia dos burros, ${ }^{2}$ Plauto faz dizer: lupus est homo homini. A diferença antropológica, a diferença do homem está em perigo desde a origem; o "animal político dotado de linguagem”* é um quase-animal, uma besta problemática, doente, uma natureza dissociada, "cujas qualidades ainda não foram fixadas". ${ }^{*} \mathrm{O}$ tomismo, apoiando-se em Aristóteles, formula uma doutrina inversa ao dogma que geralmente se tirou de Plauto: omnis homo naturaliter omni homini est

\footnotetext{
${ }^{1}$ Introdução inédita do livro homônimo a ser publicado em 2011 pela editora francesa Le Bruit du Temps.

${ }^{2} \mathrm{E}$ em seu Trinummus (II, 4, 46). A Comédia dos Burros diz exatamente o seguinte, pela boca do mercador: "Você nunca fará com que eu lhe confie este dinheiro sem saber quem você é. Quando não o conhecemos, o homem não é um homem, é um lobo para o homem (lupus est homo homini non homo, quom qualis sit non novit)." (II, 4, 86.) A afirmação não é geral. Mas a fórmula de Plauto é abundantemente retomada em Montaigne, Rabelais, Bacon, Diderot (que vê nela uma generalização abusiva) etc.

${ }^{3}$ Nietzsche é um grande leitor de Emerson (ver STACK, George. Nietzsche and Emerson: an elective affinity. Ohio University Press, 1992). Arnold Gehlen afirmará, em 1940, a pesada tarefa do animal humano, que não dispõe de um mundo preestabelecido (Man: his nature and place in the world. Columbia University Press, 1988).
} 
amicus ("todo homem é naturalmente amigo de todo homem").* Mas a máxima homo homini amicus é afirmada porque o combate, físico e espiritual, se multiplica no mundo: a violência é o segredo do direito e da amizade, e do direito à expressão em meio a uns e outros. ${ }^{4}$ Robert Burton escreve, no início de Anatomia da melancolia: Homo lupus, homo homini daemon. Com firmeza, ele designa melancolicamente a ambivalência recíproca dos homens a despeito de seu desejo de comunicação, a constante possibilidade da guerra expressa. Se Terêncio é autor do famoso homo sum, humani nihil a me alienum puto ("sou homem, nada do que é humano me é estrangeiro"), ${ }^{5 *}$ ele também escreve Hem vir viro quid praestat (“Ah! Como há distância de um homem a outro!”), * em uma expressão que é comentada no capítulo 42 dos Ensaios de Montaigne ("Da Desigualdade que há entre nós"): "Há mais distância de tal a tal homem do que de tal homem a tal animal". ${ }^{6 *}$ Para Hobbes, "no estado de natureza, o homem é um lobo para o homem" (tese a que se opõe Rousseau), mas "no estado de sociedade, o homem é um deus para o homem". 'A tese da "guerra 'natural' de todos contra todos" é exposta no capítulo XIII do Leviatã (1651). Em De cive, ${ }^{*}$ Hobbes opõe fundamentalmente o povo, "espécie de unidade que tem uma vontade única”, à multidão, e o Um tornado político ao agregado selvagem cujo retorno ameaçador é interditado pela lei.

\footnotetext{
${ }^{4}$ Sobre os conflitos contemporâneos em torno da liberdade de expressão, ver Agnès Tricoire. Petit traité de la liberte de création. Paris: La Découverte, 2011.

${ }^{5}$ Trata-se do Carrasco de si mesmo (inspirado em Menandro), que inspira o poema de Baudelaire. Marx aprecia a máxima, retirada de seu contexto; dela Cremes, o herói da comédia de Terêncio, deduz a possibilidade de intrometer-se na vida de outrem e fazê-lo trabalhar para si, logo, a possibilidade da alienação. Cícero (Des Devoirs, 1, 9, 30) lamenta que a máxima (já retirada do contexto "cômico") seja mais pregada do que realmente buscada. Da possível reação do público à fórmula de Cremes (uma torrente de aplausos), Agostinho deduz a proximidade espiritual dos homens no coração do dilúvio descrito pelo tratado De la cité de Dieu: "Naturalmente, o laço entre as almas humanas (societas humanorum animorum) atingiu a sensibilidade de todos (omnium affectum) ao ponto de não se encontrar no público nenhum homem que não se sentisse o próximo de todo ser humano, qualquer que fosse (ut nullus ibi hominum nisi cuiuslibet hominis proximum se esse sentiret)." (Carta, CLV)

${ }^{6}$ Montaigne se apoia em Plutarco.

${ }^{7}$ Cf. Epístola dedicatória do De cive. John Owen já havia utilizado a fórmula em um epigrama. O Dicionário das sentenças de Tosi cita também as Intercenais de Leon Battista Alberti (homines hominibus nocuos esse), o fragmento $451 \mathrm{~B}$ dos Pensamentos de Pascal, o Fausto de Goethe (II, 2), Notre-Dame de Paris, 7, 4 (Homo homini monstrum).
}

* (Somme Théologique, IIII, 114, 1.)

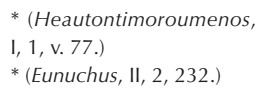

* (Essais, Livro I, cap. 42.) 
* (Tratado político, III.)

* (Carta 50, para Jelles, 2 de junho de 1674.)

* (Carta XCV a Lucílio.)

* (AGAMBEN, Giorgio. Homo Sacer: le pouvoir souverain et la vie nue. Paris: Seuil, 1998.)
Spinoza lhe oporá a doutrina da potentia multitudinis* e a continuidade do estado de natureza ao estado de sociedade.*

Um Adágio de Erasmo dizia em 1500: Homo homini aut deus aut lupus. "Ou o homem é um deus ou então é um lobo para o homem." A antiga báscula antropológica se havia velado na frase de Sêneca: homo, sacra res homini* "o homem é coisa sagrada para o homem". A sacralidade do homem para o homem é uma ideia em que ressoa ao mesmo tempo a separação aurática e contraditória de cada um e a dificuldade de um sacrificio de qualquer um. É sacrificável o homem que tem um valor separado. Mas os homens jamais se resolvem simplesmente pela separação; o sagrado é apenas a proximidade no distante, e deve assegurar a unidade imanente dos não separados, dos múltiplos seres profanos e associados, os não sacrificáveis, ou os insubstituíveis, aos direitos declarados inalienáveis. O homo sacer, este homem sagrado é, no direito romano, devolvido à sua nudez e puramente exposto, privado de direitos cívicos, ao mesmo tempo matável e não susceptível de ser religiosamente oferecido em sacrifício.* $\mathrm{O}$ exílio é a possível consequência de um sacrifício cívico, de uma privação de direitos no cerne do direito. Os direitos do homem são direitos constantemente revisados contra seu próprio princípio em razão da violência que afeta a sacralidade do humano. O duplo sentido do sagrado revela, portanto, uma irredutibilidade da violência, que a literatura não somente trata, mas afronta em cada um. Há poucos "monstros sagrados", estes "atores monstros" a um só tempo isolados e cheios de direitos, que são em princípio o contrário dos exilados, e esse poucos tem ainda por causa o desejo de estar com os outros, e de expressar-se entre eles, de fazer ouvir sua voz na inseparação. Mas há muitos exilados-refugiados que o direito das pessoas tenta abraçar. Sua vida "não literária" compartilha, contudo, um espaço comum com todas as vítimas ordinárias do desejo de literatura. Pierre Leroux escreve em 1845, com o sotaque de Agostinho: "Se considerarmos o mundo, vemos nele tudo em guerra: as espécies se devoram, os elementos lutam juntos; a sociedade é em vários aspectos uma luta contínua e uma guerra. Quantos filósofos acharam que o mais cruel inimigo do homem era o homem! O mundo que habitamos é formado apenas de ruínas, e não podemos dar um passo nele sem destruí-lo. Quer tomemos este mundo no tempo ou no espaço, sob suas duas dimensões, é uma rede de mal, de destruição e de carnificina, tão bem tecido e tão pleno que se assemelha 
àquele quadro de Salvator, em que tudo mata e é morto ao mesmo tempo, em que homens, cavalos, e até mesmo um pássaro que passa sobre o campo de batalha, tudo é atingido, tudo morre, sob um céu pálido, em um terrível precipício, enquanto o sol se apaga tristemente no horizonte. Admirável quadro, sublime expressão da melancolia que o mal moral e o mal físico espalhados no mundo podem lançar em nossa alma! São Paulo, o grande poeta, o grande teólogo, resumiu em uma palavra essa dor universal da natureza, quando disse: omnis creatura ingemiscit, e a teologia cristã não foi a única a constatar esse gemido de toda criatura." ${ }^{*}$ Cada um, capaz de gemer, é homem e reúne o múltiplo da humanidade em um, e a "vida do espírito" - a história - multiplica os casos da exposição comum ao mal difícil de ser pensado. A concorrência infinita das máximas sobre as relações humanas, ou a dupla máxima sobre a permanente destruição e reconstrução das relações explica a nostalgia de um estado de sociedade em que desapareceria a oscilação entre a transparência sonhada e o obstáculo insistente. Cada um está disposto a sacrificar o outro famoso que é o "próximo", que tem móbeis semelhantes. A concorrência das soberanias múltiplas funda o princípio elegíaco, o lamento combativo de uns e outros na "fome futura" (Hobbes) e a constante literatura que obriga a bem ver o defeito e o perigo das relações. Uma antropologia duvidosa e dolorosa apoiou-se no defeito: "O homem é um animal secreto e oculto.”* Mas um segredo se descobre. A infinita escrita provém da infinita separação dos humanos, ou corte de Aristófanes. ${ }^{9}$ Para o melhor e o pior. Simetricamente, a literatura entretém infinitamente os apetites múltiplos, dando lugar a uma multidão expressiva. A separação fará escrever "enquanto houver tinta e papel no mundo".* Não evoco esses poucos elementos de antropologia para começar um tratado de política nem para uma "Continuação do discurso das misérias deste tempo" (Ronsard); posto o quadro, trata-se de um problema especial, de porte particular, e de

\footnotetext{
${ }^{8}$ A posição não clerical de Leroux, admirada por Heine, foi, contudo, analisada por Jacques Viard em seu artigo "Pierre Leroux et les romantiques" (Romantisme, 1982, vol.12: 27-50), no qual se encontra criticada a tese de Eugène de Méricourt sobre a evolução cristã de Leroux.

${ }^{9}$ O Banquete, 189d-192e, conta o famoso mito de Aristófanes. A divisão implica a busca tensa da metade supostamente faltosa. O indivíduo é um dividido primeiro, portanto um insatisfeito, uma antiga plenitude suposta, inencontrável e buscada; a insígnia do pensamento supóe a arte de não encontrar o que se busca.
}

* (DORLÉANS, Louis. Le Banquet du comte d'Arété, 1594.)

* (MONTAIGNE. "Da vaidade", III, 9.) 
* (PLATÃO. República, 364e.)

* (SIMONDON, Gilbert. L'individu et sa genèse physico-biologique. Paris, PUF, 1964, reedição. Grenoble, Jérôme Millon, 1995: 30.) uma "Introdução ao mundo da discórdia", para desviar a expressão autobiográfica de Quincey.

O problema pode ser resumido inicialmente a uma questão: como pensar a rivalidade de milhões de escreventes daqui por diante, e do papel da escrita na rivalidade que engendra o obstáculo? ${ }^{10} \mathrm{~A}$ questão não é secundária. Naturalmente, se a resistente dificuldade de compor uma sociedade arrazoada constitui o tema de muitos textos, ela não é um tema entre outros. É uma "envelhecida matéria” (Chastelain). Nenhum escrito pode tratar isso de longe. Afirmaremos aqui que o gosto comum pela escrita - esta impressionante espécie de entusiasmo, que implica um "tumulto de livros" (biblôn homadon)* - é uma consequência do desejo de afirmação no obstáculo, e que ele entretém a opacidade entre uns e outros por meio da multiplicação e do combate das necessidades de expressão. Pois o impulso para expressar-se em língua é agora a coisa do mundo mais compartilhada. A contenda literária se desdobra certamente por meio de um fenômeno de transdução, bem descrito em Simondon: "uma operação, física, biológica, mental, social, por meio da qual uma atividade se propaga progressivamente no interior de um domínio, fundando essa propagação em uma estruturação do domínio operada aqui e ali: cada região de estrutura constituída serve à região seguinte de princípio de constituição, de modo que uma modificação se estende progressivamente ao mesmo que essa operação estruturante."* Cada ser porta um texto irradiante e se vê levado a exportá-lo, quando a guerra e a miséria explícitas não apagam essa necessidade profunda e rude. ${ }^{11} \mathrm{~A}$ remissão aos estudos

\footnotetext{
${ }^{10}$ A última investigação ou "recensão" contabiliza assim na França 55 mil escritores que publicam no sentido clássico. É evidente que no sentido amplo é preciso conceber várias centenas de milhares.

${ }^{11}$ Em Vies ordinaires, vie précaires (Paris: Seuil, 2007), Guillaume le Blanc distingue "a voz das minorias e as vozes dos 'sem-voz". Ele define "a ausência de palavra [...], uma forma de defecção anormal, que não oferece mais sequer a possibilidade aos indivíduos de se fazerem ouvir" (:141) Mais adiante (:181), ele nota, contudo, que "a insatisfação da vulnerabilidade pode suscitar um voto de autonomia”. Nesse voto se ancora a possibilidade de falar e de escrever em seu próprio nome. Sandra Laugier, lendo Cavell, resume o ponto: "Se os outros sufocam minha voz, falam por mim, sempre parecerei consentir. Não se tem uma voz, sua própria voz, por natureza: é preciso encontrá-la para falar em nome dos outros e deixá-los falar em seu nome. Se minhas palavras não são aceitas pelos outros, perco mais do que a linguagem: minha voz." (Wittgenstein, le mythe de l'inexpressivité. Paris: Vrin, 2010: 82.) Em Les Voix de la Raison (1979), Cavell diz muito bem: “A alternativa a falar em meu nome próprio a título representativo (com o consentimento de alguma outra pessoa) não é pois a de falar em meu nome a título priva-
} 
(o retorno a si), que é um efeito centrípeto das violências sociais e políticas, se completa com uma saída para a literatura, saída admitida ou autorizada, efeito centrífugo de uma necessidade de explicação e de compreensão. A infinita literatura, transportada por cada intimidade, cresce, e, sobretudo, sai, tornando-se elemento cotidiano da Rede do mundo. O vasto desejo da literatura, a grande cobiça pela publicação, avidez espiritual de massa, é um dos fatos mais disseminados e menos pensados: um dos mais comuns, com seu dilúvio de livros que não espanta mais e que a indústria da madeira não explica. ${ }^{12}$ A vaga atração pelos "quinze minutos de glória" não basta para explicá-lo: a obra é duração, e é a duração sólida, o bronze da memória e do reconhecimento, assim como a compreensão da situação de cada um, impressionada-impressionante, que fazem o sonho dos mortais concorrentes. Mais exatamente: o reconhecimento sonhado é o reconhecimento da análise geral que cada um porta e exporta à razão de suas penas. Aos olhos de todos, a literatura não é apenas um dos lugares do conflito entre os humanos; ela constitui um lugar decisivo para a compreensão e a modificação das relaçôes entre eles, um lugar crítico, capaz de agravar maciçamente a situação da qual ele é um dos sinais. Não é seguro que o filistinismo tão inteligentemente descrito por Stevenson tenha a mesma forma hoje: "Há uma coisa que vocês nunca poderão fazer com que os filisteus compreendam, uma coisa que se encontra na superfície e permanece, contudo, tão inapreensível para a mente deles quanto um arroubo metafísico; a saber, que quem se encarrega do caso da vida é principalmente a arte difícil da literatura; e que é de acordo com sua competência nessa arte que um homem conhecerá a liberdade e a plenitude de suas relações com os outros homens." ${ }^{13 *}$ Uma tal ideia da literatura, ambiciosa, órfi-

do, mas a de não ter nada a dizer, a de ser, nem mesmo mudo: sem voz." (Paris: Seuil, 1996: 63. Tradução de Sandra Laugier e Nicole Balso.) Em suma, trata-se do medo de ser privado do próprio desejo de expressão; o puro desejo de expressão culmina, contudo, na situação do desejo de comunicação no vazio, descrito por Deleuze. Cavell chega ao ponto de afirmar "a vulnerabilidade sem fim da ação humana" (Un ton pour la philosophie).

${ }^{12} \mathrm{O}$ "controle" da "escrita em relação provavelmente com o desenvolvimento das atividades de troca" e, portanto, a "elaboração contínua de uma cultura urbana e mercantil" não podem explicar por si sós o "processo de intensificação" unitário das "atividades no âmbito de um quadro a longo prazo" que caracteriza o Ocidente de acordo com Jack Godoy (Le Vol de l'histoire. Paris: Gallimard, 2010: 415-417).

${ }^{13}$ Encontramos ainda no ensaio de James esta frase: "Só havia uma única coisa
* (STEVENSON, Robert Louis, citado por JAMES, Henry "Robert Louis Stevenson". In: LE BRIS, Michel. Une amitié littéraire: Henry James / Robert Louis Stevenson. Paris: Payot, 1994: 330.) 
ca, é nada menos do que simples ou evidente, mesmo que, justamente, a imensa maioria dos escreventes a compartilhe. Como a literatura pode garantir sua aptidão a "encarregar-se" da dificuldade da vida geral, que ela reflete na maior parte dos casos? A questão se põe, em regime niilista. ${ }^{14} \mathrm{O}$ filistinismo se estende à percepção literária da vida. "A arte difícil da literatura", em razão de sua fascinante responsabilidade, tenta atualmente uma enorme quantidade de homens. A garantia da força espiritual e da responsabilidade das expressóes seria encontrada se todos os humanos escrevessem e publicassem dispondo de uma ética da escrita, que é uma ética da busca do controle sobre a pena e a deploração, e o otimismo fisiológico. Será que a literatura pôde um dia apaziguar os costumes na precipitação dolorosa, e os esforços de negação imaginada que o real penoso não interdita? Será que ela dá um "sentido mais puro" ao conflito dos seres dispersos, à multidão ativa e saída, exposta, em desejo de expressão, ao antigo grande público (populum), que não se chama mais um povo, ainda que seja um povo que lê? A palavra ética, tão poderosamente traçada por tantas plumas, designa ao menos a ordem da mais justa rivalidade entre os seres de drama que formam a humanidade. É pouco e é muito: o reconhecimento de tal "quantidade intensiva" é a base de uma ética expressiva.

$\mathrm{O}$ fato da rivalidade entre os seres foi descrito de maneira implacável na quarta Ideia de uma história universal do ponto de vista cosmopolita (1784): "O meio de que se serve a natureza para levar a termo o desenvolvimento de todas as disposições humanas é o antagonismo delas na sociedade, até que este termine, no entanto, por tornar-se a causa de uma ordem conforme à lei." A "insociável sociabilidade" é definida por Kant como "a inclinação dos homens a entrar em sociedade, inclinação ligada, contudo, a uma re-

no mundo que ele amava tanto quanto a literatura - era a ausência total da literatura. E diante do presente [...] ele sempre tinha, em última instância, este reflexo: de que Samoa não era susceptível de 'estilo' - em todo caso de nenhum estilo com o qual ele pudesse encontrar uma afinidade - a não ser o de seu apetite de viver." (: 368) Kafka completa a ideia: "Não basta dizer as coisas. É preciso vivê-las. [Quanto à] língua [...], não temos o direito de nos servir dela como de um instrumento". (JANOUCH, Gustav. Conversations avec Kafka. Paris: Lettres Nouvelles: 186).

${ }^{14}$ Nas palavras de Nietzsche, a oscilação entre o pessimismo e o otimismo é um fato do niilismo reativo e incompleto, ora ativo e incuravelmente sonhador, ora desenvolto e sem ideal. A desenvoltura para o problema da multidão rival ou da horda secundária faz uma espécie de vida incompleta, que "transforma a humanidade em areia” (Aurora) - pólvora nos olhos na tempestade do deserto que crê. 
sistência geral que ameaça constantemente romper a sociedade. $\mathrm{O}$ homem possui uma tendência a associar-se, pois em um tal estado ele se sente mais do que homem, isto é, ele sente o desenvolvimento de suas disposiçôes naturais. Mas ele tem também uma grande inclinação a separar-se (a isolar-se), pois encontra ao mesmo tempo em si este atributo que é a insociabilidade, 'tendência' a querer organizar tudo sozinho de acordo com seu humor; nesse aspecto, ele espera 'encontrar' resistência por toda parte, uma vez que sabe por si mesmo que é dado, de seu lado, a resistir aos outros. Uma tal resistência excita então todas as forças do homem, levando-o a triunfar sobre sua inclinação à preguiça, e, movido pela ambição, pela sede de dominar ou de possuir, a obter um lugar entre seus companheiros, que ele não pode suportar, mas dos quais também não pode mais se privar." A dupla sanção, o amor ligado ao ódio, é o duplo fundo dramático que os homens querem precisamente aplanar ou deitar sobre o papel, ainda que fosse um papel de tela; a necessidade de escrever é a necessidade de ter o coração claro. E a autorização para escrever não suprime a escuridão do duplo fundo, o duplo postulado do acalanto, que repousa da ambivalência fazendo- a ser esquecida, e do clarim, que traz de volta ao inesquecível: a literatura não é jamais simples acalanto, e os contos dão medo. Entretanto, na ausência de clarezas sobre a obsedante dupla natureza das relações humanas, não é fácil escapar de uma das três tentações de conclusão descritas por Kant em $O$ conflito das faculdades (1798): o terrorismo apocalíptico (o sonho pio e visionário de um renascimento da humanidade após ter perecido pelo fogo), o eudemonismo (a doutrina da igual compensação dos bens e dos males a cada época) ou o abderitismo (a constatação dogmática de uma loucura da história dos homens). ${ }^{15} \mathrm{O}$ fato de rivalidade, o fato da paz como guerra continuada por outros meios, a que preço ele funda "um progresso no plano da espécie", progresso indireto e superior, submetido a uma ausência de progresso no plano individual? Fácil é a tentação de fazer com que a literatura desempenhe

\footnotetext{
${ }^{15}$ Kant, o progressista crítico, confessa em Ideia de uma história universal do ponto de vista cosmopolita: "Não podemos nos defender contra um certo humor, quando olhamos para a apresentação dos fatos e gestos na grande cena do mundo, e quando, aqui e ali, ao lado de algumas manifestações de sabedoria para casos individuais, vemos apenas no todo, ao fim das contas, um tecido de loucura, de vaidade pueril, e com frequência também de maldade gratuita e de sede de destruição. De tal maneira que, afinal não sabemos mais que conceito devemos fazer de nossa espécie tão enfatuada de sua superioridade."
} 
* (Cf. Le Temps des prophètes: Doctrines de l'âge romantique. Paris: Gallimard, 1977; Les Mages romantiques. Paris: Gallimard, 1988; L'École du désenchantement: Sainte-Beuve, Nodier, Musset, Nerval, Gautier. Paris: Gallimard, 1992.)

* (De la division du travail social, 1893.) um papel importante, direto ou indireto, no processo de socialização e de pacificação. Paul Bénichou mostrou certos móbeis modernos fundamentais da tentação.* Uma vez que a figura do mago ou do literato profético se esfumou, tardiamente, no século XIX, o mundo foi percebido como a adição de indivíduos literários autorizados a expressar-se isoladamente. Ele comercializou os pedestais da solidão. Será que a linguagem é agora o lugar democrático-estético do desejo da guerra? Não se pode reduzir a pulsão de escrever ao "furor do homem que quer se distrair" (Grandeza e decadência da cidade de Mahagonny) nem à distribuição de "doces e consoladoras palavras" (Jean Molinet).

Assim, portanto, a ideia da literatura é poderosamente difusa nas cabeças e nos corações, e nas plumas que os reúnem. Ela o é a ponto de a escrita ser permitida a todos. A Rede acelera o processo, e propõe a publicação online, a publicação das linguagens privadas. A noção de "opiniāo pública” perde preciosamente sua força, mesmo que a passagem do privado ao público seja desmedida. ${ }^{16} \mathrm{~A}$ distinção operada por Durkheim entre "solidariedade mecânica” e "solidariedade orgânica", confirmando a que Tönnies operava em 1887 entre comunidade e sociedade, complicou-se expressivamente. Nunca houve tantos publicantes, tantos rivais expressivos, cuja rivalidade una deve ser levada a sério: rivais em expressão e rivais pela expressão eles são mais do que nunca, mas sobretudo de outra maneira. Certamente houve, em outros momentos, graças à imprensa, tal "maré de publicações" (Flugschriften). Não se trata de uma realidade quantitativa, mas de outra coisa: a quantidade revela aqui uma qualidade da necessidade. A expansão da ideia da literatura não é apenas um efeito da individualização dos seres - eu gostaria de

\footnotetext{
${ }^{16}$ A oscilação entre a tese de Lippmann e a tese de Bryce pereceu. Walter Lippmann (Public Opinion, 1922 e The Phantom Public, 1925) descreve um público isolado, indiferente e incompetente, versátil e infantil, cegueira à mercê dos meios de comunicação de massa que moldam seu horizonte de expectativa ou o que Goffman chamaria de uma "ordem expressiva”. James Bryce preconiza a referência a uma classe esclarecida: a opinião pública é então o julgamento social de uma comunidade consciente em relação a uma questão de interesse geral após uma discussão racional e pública. $\mathrm{O}$ fato da multidão segunda nos obriga a ver o esgotamento da noção de opinião pública. A multidão não é uma massa homogênea; ela é um conjunto de singularidades abertas, susceptíveis de se fechar. Mas é a possível obra aberta de cada um que aparece. "Nenhuma sociedade sem classe se revela em Mahagonny como medida de um presente rejeitado." (Adorno) A "democracia do público" - expressão da politicologia - deve supostamente definir agora o conceito de literatura? A opinião pública é uma entidade definida pelo sistema da "Nova Gestão Pública".
} 
mostrar que ela tem também um efeito comum sobre os separados, se e unicamente se quisermos pensar o teor da raiva da expressão. ${ }^{17}$ Não que a individualização expressiva seja uma maravilha. $\mathrm{O}$ individualismo é "um conteúdo que se presta ao mal-entendido em um jovem auditório”, diz Sôseki em 1914. O mal-entendido afeta em seguida o auditório inteiro. "Eu não gostaria que nascesse um mal-entendido sobre o sentido da palavra "individualismo." A palavra remete a "uma solidão que não se vê". "É a tristeza inerente a todo individualismo.” Mas a individuação, enquanto processo, é susceptível de impedir a triste fixação dos indivíduos pela expressão, mesmo quando a tristeza é o bom motivo da palavra. O que um ser humano pode tirar de si mesmo, se ele se expressa como um fruto (mas um fruto é expresso e não tira espontaneamente o fruto que contém), não pode ser isolado sem consequência, uma vez que o isolamento do expresso divide o gênero humano a ponto de fazer dele uma adição de mônadas ou frutos fechados, espécies desligadas, elos pesados de uma cadeia fantasma. O prestígio do fato de escrever se explica inicialmente pelo poder geral ainda atribuído à escrita: um poder de esclarecimento. Durante muito tempo, a literatura foi poderosamente difundida entre aqueles que não escreviam. A poderosa difusão tinha como causa a autoridade comunitária de ofuscantes textos fundadores, compostos em língua una (Homero, Théognis, Hesíodo na vida grega, por exemplo). A potência difusa, após o poder difundido, é um efeito do desenvolvimento separado de cada um. Nunca foi possível a todos, como hoje, escrever, e mesmo tornar público o fruto da raiva da expressão - o que se chama publicar, se reatar à comunidade dos impulsos subjetivos. ${ }^{18} \mathrm{O}$ mundo do jeito que anda produz indivíduos literários, ${ }^{19}$

\footnotetext{
${ }^{17}$ Ponge dá a raiva um sentido positivo: "Que meu trabalho seja o de uma retificação contínua de minha expressão (sem preocupação a priori quanto à forma dessa expressão) em favor do objeto bruto." Ele sente "um gosto violento pelas coisas, e pelos progressos do espírito", contra o "rom-rom poético" (La rage de l'expression (1941). Paris: Poésie/Gallimard, 1976: 9 e ss.) Tomo a raiva no sentido neutro e descritivo do conteúdo da expressão que enraivece. ( $\mathrm{O}$ verbo enraivecer é ouvido naturalmente duas vezes.)

${ }^{18}$ Louis-Sébastien Mercier fala da "raiva de Autor". De la littérature et des littérateurs (1778). In: Dictionnaire d'un polygraphe, edição de Geneviève Bollème. Paris: 10/18, 1978: 152-153.

${ }^{19}$ A noção de "indivíduo literário" não deve ser ouvida aqui imediatamente no sentido de Daniel Oster (L'individu littéraire. Paris: PUF, 1997). O autor de La gloire (Paris: Pol, 1997), mallarmeano singular, pedestre e profundo, evoca na última página de seu livro "este homem atento à Multidão e que a vilipendia”, este "individualismo doce mas firme", "este X [...] que ninguém atinge em si". O
} 
isto é, átomos que se escrevem e se vivem em sequências de representações fraseadas e em almas culturais. São soberanos múltiplos, que não pensam seu desejo. Eles formam átomos comunicacionais destacados, indivíduos detidos ou em instância de detenção verbal, assombrados pela comunicação. Entretanto, por muito tempo, o que o Ocidente aprendeu a chamar de literatura não foi, ao menos em aparência, uma questão de expressão; ela foi transcrição e transmissão de alguma síntese escolar comandada, grande palavra anônima e mítica destinada a fundar a organização da vida - ou seja, conjunto de lições sobre o mundo em que os humanos deviam inscrever-se e a que deviam recorrer para viver. A vida da interioridade era mobiliada ou supostamente mobiliada. Nem tédio nem desamparo tinham sentido em princípio. A melancolia era estudiosa ou preenchida, e vetorizada. A literatura, escoltada em torno de um fogo, aquecendo, e nutrindo como uma segunda terra, foi o doce tirano, o repousante terror de cada um, porque era escutada sem que se escrevesse, como se escuta uma concha; ela criava comuns sensaçôes pedagógicas. ${ }^{20}$ Ninguém havia criado o mito. Ele se tinha inventado, transcrito de uma descoberta no fundo antigo

kantismo do autor o impede de chegar ao princípio de Guys, que se resumiria à recusa do princípio de Horácio: non odi profanum vulgus, non arceo, diria aquele que vê na noção de "indivíduo literário" mais do que um paradoxo, uma contradição. Oster pergunta: “Eu me expresso’: o que significa essa afirmação, esse projeto? [...] Em que mitologia tirânica deve sempre esconder-se aquele que pretende revelar-se?" (: 7) A questão complica a proposição anterior: "Uma vez que cada homem é sua ficção, quem escreve é, talvez, nisso mais homem." (: 1) Sem colocar a questão da multidão literária, Oster coloca a inevitável questão da necessidade: "Em que condições escrever é desejável? [...] Isso não é evidente. [...] $\mathrm{O}$ que acontece quando o desejo se faz primeiramente lei, e depois submissão à Lei?” (: 7) A profunda página 59 da obra elabora a noção de postura enunciati$v a$, que estabelece o elo fundamental e difícil entre o pensamento de um sujeito, a enunciação, a escrita e a literatura. Ele escreve, mas no modo condicional: "A distinção entre escrita e literatura teria de todo modo a vantagem de permitir distinguir metodicamente a singularidade que adviria a si na enunciação e a singularidade autoconstituinte e autodefinidora do discurso." Onde começa "a instância performativa de um 'eu sou singular”"? Se este último enunciado é a fiç̧ão da enunciação, então "o surgimento do 'eu' no discurso não daria testemunho do investimento abalador de um sujeito em sua palavra, mas da postura enunciativa que ele adota para suscitar a crença nesse surgimento." O kantismo da ficção suprime ou inquieta a distinção entre o impulso de se pensar, dizer, escrever constituindo-se e o impulso de se moldar em língua dita literária.

${ }^{20}$ Cf. Lettres sur l'éducation esthétique de l'homme. Schiller sustenta que o "caráter natural do homem é egoísta e violento, e visa mais à destruição (Zerstörung) do que à conservação (Erhaltung) da sociedade". (Terceira Carta) Ver também o ensaio de Benjamin sobre Berlin Alexanderplatz, "Crise do romance". 
da verdade una. O escritor, espécie de intermediário superior, era a exceção, até mesmo o nome de um gesto sem biografia. Homero é possivelmente o nome próprio de uma escola de inventores de histórias. ${ }^{21} \mathrm{O}$ grande número escutava os intermediários secundários - os "passadores" chamados rapsodos, por exemplo -, e não escrevia, não pensava em escrever. As histórias primeiras vinham a eles. Naturalmente, é possível hoje a cada um escrever, pois a literatura autoritária e maravilhosa, suave e repousante como uma autoridade transmitida do fundo dos tempos (fundo sem fundo), é um modelo antigo, inatual e coercitivo; nenhum novo Dante aparece, mas Dante é ainda um modelo. $\mathrm{O}$ molde se quebrou, cada um na crise pode verificar o problema das narrativas primeiras, mas a noção do "pós-moderno" está longe de suprimir a modernidade do antigo nas cabeças e nos coraçôes. No entanto, as tentativas épicas posteriores a Dante não se assemelham à sua.

Erich Auerbach descreveu a exata relação de Dante com seu leitor em uma singular época intermediária. A passagem merece ser citada quando o hipócrita leitor pode escrever e contestar aos outros leitores, leitores irmãos, o direito de escrever: "O que é notável aqui [...] é a mistura excepcional de fraternidade e de autoridade em relação ao leitor; o leitor é convocado e exortado a seguir ele próprio seu caminho na direção indicada. [...] Dante realmente indicoulhe com clareza o caminho que devem tomar seus pensamentos. [...] Mesmo que possa ter a impressão de que o não dito é indizível e de que o segredo não é comunicável, ele é sempre incitado a buscá-lo e a aprofundar sua significação. Os endereçamentos ao leitor são sempre redigidos no imperativo, eles não contêm nenhuma solicitação de favor ou de indulgência; e em parte alguma Dante fala como um autor que considerasse o público como clientes. Quando diz que espera favores e renome, Dante parece endereçar-se a um futuro distante, e no momento em que admite sua impotência, não pede ao leitor indulgência, mas compreensão quanto ao peso da tarefa, pois esta ultrapassa em muito a força de ombros humanos. [...] Mas o imperativo, que vem ao encontro do leitor no poe-

\footnotetext{
${ }^{21}$ Homero é certamente a mais pura confirmação a priori da observação de Borges em seu ensaio "Sobre o Vathek de William Beckford": "A realidade é tão complexa, a história tão fragmentária e simplificada, que um observador onisciente poderia redigir um número indefinido, e quase infinito, de biografias de um homem, e cada uma delas destacaria um grupo de fatos independentes, e precisaríamos ler um grande número delas antes de compreender que se trata de um personagem único.”
} 
* (Langage littéraire et public dans l'Antiquité latine tardive et au Moyen Age (Literatursprache und Publikum in der lateinischen Spätantike und im Mittelalter, 1958). Tradução de Robert Kahn. Paris: Belin, 2009.)

* no Túnel dos Irmãos Lobos

* (Jean Bouchet, Les Regnars traversant les périlleuses voyes des folles fiances du monde, 1503.) ma, tem também uma maneira própria de ganhar a simpatia dele, chamando-o e conjurando-o; ele faz do leitor um contemporâneo, incessantemente desafiado e incitado. Toda a sua personalidade é levada em conta."* É a hierarquia que se estabelece na fraternidade que agora nos é velada, com um princípio de simpatia condicional. Estamos no túnel do "interregno" (Mallarmé), * sem nada saber do reino futuro, se reino há. $\mathrm{O}$ contrato de dissimetria relativa começa, talvez, com Dante. O leitor não é o outro deste escritor do qual ele é distinto na prática: "A apóstrofe obriga o leitor a uma participação muito intensa: ela une mais fortemente entre si aqueles que seguem Dante, e com ele [...]. Ao repelir, Dante atrai, exige e une; ao parecer a cada momento prometer mais do que diz e do que é dizível (que o leitor apenas estique o pescoço na direção do pão dos anjos), ele o liga ao objeto inesgotável [...]; pois é evidentemente o objeto que o autoriza a segurar o leitor com uma mão tão direta e forte. $\mathrm{O}$ objeto é a ordem divina do universo, não enquanto sistema doutrinal, mas enquanto visão direta de um homem que comunica essa visão a outros, que não a experimentaram; o que confere a ele, ao anunciador, uma incrível autoridade, e suscita no leitor ou no ouvinte o mais alto interesse quanto a esse anúncio." ${ }^{22} \mathrm{O}$ ser ledor, mesmo quando lhe ensinam um sistema do mundo, não está mais em repouso. "Recriar o entendimento dos ledores" ${ }^{23 *}$ não é desviá-lo de sua força. A causa de Dante já é a persistente e preocupante dureza do mundo. Alguém, quando a generalidade toma a pluma, tenta se ocupar disso, ou mostrar como o mundo avança. Nenhuma epopeia erudita escandida po-

\footnotetext{
22 Sobre a auctoritas, ver "O conceito de autoridade", de Hanna Arendt, em $A$ crise da cultura (Between past and future, 1961-1968). Trata-se das condiçōes da autoridade de um autor. A partir do que se autoriza ele, e o que é que o autoriza a escrever - a ampliar a humanidade - se passado e tradição não são mais sinônimos? O passado deve ser experimentado sem a orgânica submissão à continuidade da origem ( $\mathrm{O}$ conceito de tradição é o fundamento da obra de MacIntyre, After Virtue (1981), para criticar "o individualismo herdado das Luzes". O racionalismo individual é considerado como a causa do caos, para o qual o único remédio é encontrado em "uma tradição das práticas".)

${ }^{23}$ A recreatio é reconforto, isto é, convalescença e reforço, restabelecimento mais por repouso do que pelo "divertimento" no sentido de Pascal, isto é, distração e abandono; os prosímetros medievais alternam os versos recriadores ou recreadores e as prosas didáticas, não desviando destas últimas, mas levando de volta a elas com força, como a diversão [amusement] que reconduz à Musa, ao "Labor historiador" (Jean Lemaire de Belges) - procedimento diferente do da Vita nova, onde o poema ou verso tensiona o leitor, e a prosa explica os versos. Dante tensiona e distensiona ao mesmo tempo, em uma forte continuidade ritmada.
} 
de apaziguar o leitor, encantar o ouvido do coração como a beira do mar onde o fogo aquecia as almas cativas clareando as ondas na noite calma e sem batalha. Auerbach mostra a situação paradoxal de um escritor que, não apenas não escreve mais na língua latina, autorizadora e una, e escolhe o volgare, supondo, pois, a posteridade de Babel, o futuro da diferença das línguas, o futuro da separação, aliás, como também se esforça para unir as pessoas leitoras ao objeto universal cuja autoridade vacila. A tradição rachou-se discretamente no centro da Idade Média, e o olho ouve sem se apoiar inteiramente no antigo rumor da escola: "Dante criou seu público, mas não o criou apenas para si mesmo. [...] Quando escrevia, pouco depois de 1300, a difusão da escrita e da leitura, assim como a necessidade de distração literária e de nutrição intelectual, deviam estar praticamente no mesmo estágio, em várias zonas da Europa Ocidental, que na Itália romana pouco antes da época clássica. Mas a situação era completamente diferente, mais confusa, mais heterogênea e mais rica em possiblidades.* A ascensão progressiva das línguas vulgares levou também à expressão de outros movimentos intelectuais, menos facilmente assimiláveis ou mais inquietantes por suas implicações: correntes políticas que apareciam na maioria das vezes sob a forma de heresias cristãs, ou que começavam a arriscar uma tendência a liberar e a tornar absolutas paixões humanas afirmadas em sua subjetividade trágica, independente dos sofrimentos do Cristo. Esse movimento se produziu na cultura cortês [...]. Havia certamente muitas tentativas de compromisso, ensaios de interpretação em um sentido cristão da busca a-histórica de aventura (queste) e do amor cavalheiresco (Minne): mas era um subjetivismo até então desconhecido que aparecia assim, uma liberdade e uma dignidade nova da paixão. [...] Na Divina Comédia, Dante integrou o aqui e o agora histórico dos destinos e das paixões humanas na ordem divina; ele abraçava tudo e era ao mesmo tempo atual. [...] Ninguém pôde prosseguir ou reelaborar a totalidade da concepção do mundo e da história proposta por sua obra, pois ela ruiu, sua parte histórica ainda mais rapidamente que sua parte física. Nada de semelhante a substituiu, e nenhum poeta do mundo terrestre pôde, por causa disso, endereçar-se ao leitor com a mesma autoridade, a do iniciado pela graça divina."

A Comédia humana faz descer o sistema de Dante, que ele transpõe. Fantasmagoria terrestre, enciclopédia limitada, ela supõe e detalha a prosa do mundo social. O leitor de Balzac é seu aluno 
cúmplice e indeterminado. É um homem do mundo. O ser ledor não é mais um ouvinte cativo, ele aprende a escrever e, principalmente, habituou-se à possibilidade de escrever: a popularidade dos jornais é primeiramente a prova do aumento do número daqueles que têm o direito de escrever, antes de ser a prova de que muitos sabem ler. O "fervor leitor" a que Whitman se endereça em 1871 em suas "Vistas democráticas" sabe que "o povo inteiro de nossa terra pode ler e escrever". Ele se refere, entretanto, ao "grande letrado moderno", ao "divino letrado" em lugar do "padre" e, finalmente, "a uma classe [...] de autores autóctones [...], sacerdotal [...], própria para afrontar nossas circunstâncias", pois "o problema da humanidade [...] quer ser abordado e tratado pela literatura." Falou-se do autoritarismo de Balzac, mas pouco se notou sua recusa dos endereçamentos paródicos e condescendentes "ao leitor", apreciados por Sterne, Diderot ("Cabe apenas a mim...”), Stendhal, e até Hugo. ${ }^{24}$ A cumplicidade do acesso ao saber se funda na indeterminação do leitor: "Cada um adivinha que a fachada..." (Os Camponeses). O destinatário é um pronome: "se [on]", "aqueles que"; o narrador escreve às "pessoas para as quais" o escrito tem interesse. Uma pedagogia sem suficiência funda a abertura que uma época impõe profundamente. A destinação começa a mostrar sua natureza incalculável e refletida. É o sentido das "conversas com o público" que Zola atribui a Balzac. Pode-se ler, em uma observação acrescentada em 1846 ao Elixir da longa vida: "A leitura nos proporciona amigos desconhecidos, e não há amigo como um leitor! Temos amigos conhecidos que nada leem de nós." O desconhecido é o irmão lobo. O leitor de Dante não podia ser um completo desconhecido; era um desconhecido iniciante, na vacilação do mundo que o explicava em princípio.

O primeiro romantismo foi, até a ironia fragmentada (e não a simples fragmentação irônica), ardente consciência do esgotamento de uma literatura fundadora, literatura dos cordeiros, "Bíblia de um povo", "bíblia popular", "livro nacional”, "bíblia épica”, "bíblia religiosa" ou "bíblia poética" (Hegel varia as expressōes). ${ }^{25} \mathrm{O}$ projeto de teatro épico, a um só tempo didático e descontraído,

${ }^{24} \mathrm{O}$ início de La légende des siècles é dito de cima, na onisciência sonhada: "Tive um sonho; o muro dos séculos apareceu para mim." Condescendência séria, que é a postura do mago de Les Misérables.

${ }^{25}$ Estética, terceira parte, terceira seção, capítulo III, 3, A, "A poesia épica”. No capítulo seguinte, ele afirma que "a poesia lírica não tem que mostrar bíblias poéticas". 
assinado pelo nome de Brecht no século XX, não pôde superar a causa do esgotamento, que é a "crise da cultura", isto é, da tradição. Entretanto, a literatura prosperou, absolutamente. "Se o velho mundo não existe mais, ele se encontra, no entanto, mais vivo do que nunca."* A imensa popularidade do romance, que se sonha primeiramente como epopeia em prosa, parôdia, dublê da Grande Narrativa, e depois "moderna epopeia burguesa", é um dos principais sinais do estranho gosto comum pela escrita, quando as pessoas têm o lazer de escrever. ${ }^{26}$ Esse gosto havia sido preparado desde muito tempo; Platão, tão desconfiado em relação aos contos de dar sono, o prevê e o teme com atenção, pois o inventor da escrita era um sutil deus do Egito. ${ }^{27 *}$ Horácio vê uma razão "egípcia” na escrita: a ereção, contra o tempo, de um monumento "mais durável do que o bronze (aere perennius)".* Mas é para melhor atravessar o tempo que se dá matéria à memória (transit scribendo). Um fenômeno impressiona o observador: a fascinação pela escrita publica$d a$ cresce tranquilamente, amplamente, ao mesmo tempo em que quantidades industriais de escreventes publicantes, em sua maior parte narradores, florescem no mundo, movendo-se ao sabor dos "encontros literários" ou festivais no melhor dos casos, colocados em estufas aleatórias em que as liberdades ao léu, sonhos de duração, funcionam em vasos. Quando não viajam ao país dos ouvintes, aqueles que expõem suas escritas são as aranhas sedentárias da Rede. Os publicantes, que são flores de sociedade e amam as flores de literatura, percebem-se uns aos outros como puros desconhecidos logo esquecidos, mantos com nomes provisórios: vasos decorados se avizinham de vasos decorados, de onde brotam sonhos de monumento. Às vezes, algumas plantas de viagem têm um nome, o

\footnotetext{
${ }^{26}$ A prática da literatura não está mais reservada a uma "classe de lazer", no sentido de Veblen. O "desejo de elegância" não está mais reservado a uma classe, e não pode ser reduzido, ao menos quando se trata da escrita, à exibição de um "lustre do tecido", que seria causado por um "consumo ostentatório". Se a predação literária condiciona o artesanato dos textos, os efeitos dessa predação democrática devem ser pensados. Mas a aristocracia difusa tem também suas travas de segurança. Tratarei da questão especialmente nos capítulos IV e IX deste livro (cf. nota 1).

${ }^{27}$ Platão não é Pirro; ele não desprezou o escrito; quarenta e dois diálogos o provam. A escola de Tübingen constrói sobre areia. Não há conflito entre o oral e o escrito; há conflito entre a logografia e o manejo sério do discurso que não implica uma misologia (um ódio da linguagem): "não há em si nada de feio em escrever discursos..." (258d). É preciso privilegiar "o discurso interior daquele que sabe" (276a), isto é, o pensamento, e não se remeter à memória passiva (275c-d). A escrita não é apenas hipomnese, suporte, ferramenta da preguiça.
}

* (MANDELSTAM, Ossip.

"Verbe et culture".)

*(Cf. PLATÃO. Fedro, 245b$279 \mathrm{~b}$, especialmente $274 \mathrm{~b}-$ 278 e, e Carta VII, 342a$345 \mathrm{c}$.)

*(Odes, III, 24, v.1.) 
* (Notes sur la littérature. Tradução de Sybille Muller. Paris: Flammarion, ANO, p. 421 e ss.) índice de uma travessia do tempo. Chegará o dia em que a publicação será um direito imprescritível na Cultura da expressão, até mesmo o dever de todos, sob a condição que o candidato à publicação - que é primeiramente o Candidato ao Texto - não seja declarado uma pré-pessoa ${ }^{28}$; chegará o dia em que todo escrevente público será o objeto de uma monografia (de um arquivo monográfico) entre os inúmeros dedicados às singularidades consentidas.

A situação descrita por Adorno em 1938 e 1967 deve ainda ser nuançada à luz de certos desmoronamentos. Encontramos um dos resumos mais agudos da descrição na "Carta aberta a Rolf Hochhuth".* A "ideologia do particular" faz com que se esqueça que o indivíduo não é "uma categoria da natureza”, mas "um ser histórico, isto é, que surge graças ao trabalho [...]. Mas se o indivíduo é algo que surgiu, não existe organização do ser para velar para que ele não desapareça da mesma maneira." Convém, portanto, distinguir entre uma análise geral do indivíduo e de seus impulsos e uma análise histórica. A análise geral deve levar em conta a história: “À grande literatura não faltam exemplos para provar que a recolocação em questão do homem isolado, determinando-se a si mesmo, não data de hoje." O hoje de Adorno deixava discernir um "declínio da individualidade", já nada menos do que simples no plano geral: "A individualidade não é simplesmente o ser biológico isolado, mas sua forma refletida pela razão, graças à qual ele se mantém como um particular." A nuança deve intervir na interpretação da constatação de história: "As forças coletivas liquidam [...] a individualidade que é impossível salvar, mas apenas os indivíduos são capazes, diante delas e conhecendo-as, de representar ainda as reivindicações da coletividade." É bastante evidente que o termo coletividade, por causa da fragmentação dos impulsos coletivos, perdeu seu uso no hoje de 2010. A constatação é igualmente histórica, mas "compreender o que um processo tem de coercitivo não é aprová-lo" ${ }^{29} \mathrm{~A}$ individualidade salvável só pode aparecer em relação com a coletivização fragmentada da literatura. Será aceita em uma outra perspectiva a frase seguinte: "O indivíduo também tem uma parte de responsabilidade nesse infortúnio. O que ele sofre hoje,

${ }^{28} \mathrm{O}$ conceito se dramatiza no conto de Philip K. Dick "Les pré-personnes”, no qual seres "passam pelo teste da alma”. Até a idade de doze anos, toda criança pode ser declarada sem alma e, portanto, suprimível.

29 “Reconhecer e perseguir” (Harun Farocki), “'Entender' no sentido de Vico, dizendo de outro modo, reviver e julgar..." (Pavese, "L'humanisme n'est pas une sinécure", 1949). 
ele perpetua por sua dureza e sua frieza." Seguramente "ninguém tem o direito, por orgulho elitista, de se opor à massa de que se é também um momento". Se "o conceito de indivíduo não é uma antítese suficiente" para o infortúnio, isso pode agora ser explicado pela banalização dos impulsos de massa fragmentados. O indivíduo convém ao caráter maciço ou "cordeiro" das necessidades expressivas. É doravante impossível profetizar o desparecimento do indivíduo em razão da ausência desta liberdade sonhada, que é supostamente sua causa final. ${ }^{30}$

Pois os humanos se isolam e se dispersam à razão dos desejos de escrever e de fixar as causas da dispersão, ainda que no sonho continuado da poesia universal progressiva. Mallarmé descreveu os lineamentos da "inexplicada necessidade de individualidade", * que não tange apenas a "cada poeta que vai, em seu canto, tocar numa flauta, dele mesmo, as melodias que quiser". Trata-se de uma "noção indubitável: a de que, em uma sociedade sem estabilidade, sem unidade, não se pode criar arte estável, arte definitiva. Dessa organização social inacabada, que explica ao mesmo tempo a inquietude dos espíritos, nasce a inexplicada necessidade de individualidade, cujo reflexo direto são as manifestações literárias presentes". O desejo de escrever, se não a necessidade, é um dos principais vícios impunidos, um dos mais reveladores da essência da época: ele cria o desejo de transcrever, de arquivar as dificuldades de existir nela, e as aporias do isolamento, se é que há existência. A literatura dos átomos apresenta permanentemente um estado de exceção, e a dispersão comunicante, a tirania da isenção dos particulares. Sôseki: "Considero que não se pode fazer nada contra a disparidade das opiniōes, qualquer que seja o grau de intimidade entre duas pessoas." Em 1925, Larbaud define a escrita como um vício impunido, mas é a escrita que é o vício autorizado de agora: uma escrita sem leitura, ou antes uma escrita secundariamente irrigada pelo fluxo imenso dos livros constituintes tornou-se fato orgânico observável em cada um, "merceeiro sintético, açougueiro ou banqueiro, burocrata de agora, moedeiro, padeiro ou engenheiro de sistemas ${ }^{31}$.

\footnotetext{
30 "Ao final, o indivíduo só desaparece porque ao longo da história nunca conseguiu ser livre." (Adorno).

${ }^{31}$ A ironia de Sôseki lembra, aliás, a crítica platônica da polivalência (polypragmosunè): "como se um peixeiro tivesse ido fazer seu aprendizado com um confeiteiro." Cf. PONTALIS, J.-B. Traversée des ombres. Paris: Gallimard, 2003: 168: "Escrever é um vício impunido." Antes ele cita Burton: "Não apenas nossas bibliotecas e nossas livrarias estão cheias de papel infecto, mas também as cadeiras vazadas,
}

* ("Réponse à l'enquête sur l'évolution littéraire". Em: L'Echo de Paris, 14 de março de 1892. Texto republicado em Divagations sob o título "Crise de vers".) 
A renúncia à poesia não é a causa da tirania. Hoje, um poeta-rei ou um rei-escritor são imagináveis: a realeza ao escrevente. (Civilização e cultura começam ou recomeçam com ele, na ideia.) Realeza dispersada, poder dos reizetes, que não é o poder da criança de Heráclito. Trata-se de um agravamento destes "não leitores congênitos" de que falava Mandelstam com ironia em A quarta prosa: "Aqueles que escrevem versos são, na maior parte dos casos, péssimos, desatentíssimos leitores de poesia; escrever já lhes faz mal o bastante; inverossimilmente instáveis em seus gostos, não preparados, não leitores congênitos, eles já se irritam quando são aconselhados a aprender a ler antes de querer escrever. Nunca chegariam a pensar que ler poesia possa ser uma arte, uma arte das maiores e mais difíceis, e que o título de leitor possa não ser menos respeitável que o de poeta..."

O fluxo herdado na inconsciência tornou-se literatura consciente sob o nome de Borges. Leitor perfeito. Nele, como em uma série de alocuçôes aos seres ledores (à humanidade leitora), a biblioteca universal parece circular livremente e expressar-se. Ela passa pelo homem-pluma, e parece emanar dele para nos encontrar. Ele é comunicativamente transido. Daí uma aptidão quase natural a citar literariamente, a dramatizar em promessas de felicidade as referências que abundam diretamente sobre ele. A cultura é o drama do saber numeroso em sua virtude de incitação, em sua graça de peso e de memória. Ela dá a pensar, por impressão e solicitação. Borges, modelo do Escriba Inverso, Homero sem a Fundação Dirigente, é o esquecido da sociedade de agora. A interioridade mítica é um escriba livre, que carrega o peso das novidades antigas que o ligam ao real, a sua história viva e sedimentada. Não que cada um tenha que passar por suas provas sociais, tenha que recitar antes de sonhar com a escrita: ela não é destinada a ninguém de direito (mago, aedo ou cantor), e a urbana pretensão ao estilo imitado dos artificios naturais com que sonhava a aristocracia suscitou um sonho do estilo, um desejo da elegância, não apenas em contradição com o muntodas as latrinas." O autor de Anatomia da melancolia define seu livro como uma "rapsódia de farrapos que amontoou depois de tê-los pego em diversos montes de imundícies." Grafomania de Jó, suturador... A melancolia afeta a antiga compilação, e a relação com a imensidão da biblioteca. Ela pode abrir para a criação, como mostram apaixonadamente os trabalhos de Jackie Pigeaud. Ver também $\mathrm{La}$ couleur de la mélancolie, la fréquentation des livres au XIVe siècle (1300-1415) (Paris: Hatier, 1993), onde se lê: "A tristeza do já dito se transforma em alegria do sempre escrever." Citemos alguns capítulos: "O que há de novo sob o sol claro?" O princípio de La Bruyère é contradito a priori na melancolia. 
do como ele anda, mas incapaz de sentir e de imprimir justamente seus móbeis. A incultura do desejo é sinônima do fechamento dos pensamentos, dos restos de saber que assombram alguém. Os Antigos que nos são descritos por Jaeger na Paideia são seres convencidos de que "a educação e a cultura não constituem uma teoria abstrata ou uma arte formal, distintas da estrutura objetiva da vida espiritual de uma nação", mas "encontram-se na literatura, expressão verdadeira de toda cultura superior". Uma tal convicção fundava o princípio aristocrático: o acesso ao melhor é humanamente obrigatório. Não se trata principalmente de literatura: "O mundo dos aedos e dos contadores não é propriamente literário." (Malraux) "Os heróis sentiram pelos sentidos humanos estas duas verdades [...] conservadas pelos verbos latinos educere e educare; com uma elegância suprema, o primeiro designa o que é relativo à educação da alma, e o segundo o que é relativo à educação do corpo. O primeiro, por meio de uma metáfora erudita, foi aplicado pelos físicos ao ato de fazer saírem formas da matéria..."*

Perguntamo-nos então em que estado se encontra a literatura, o coração da literatura, núcleo vivo ou bomba vital, segundo a metáfora adotada. Buscamos ainda seres para encontrar esse coração e nos educar no encontro. Não é absolutamente um jogo de palavras. A pulsão da literatura não exerce o papel de "cultura civilizada". É preciso ver também o estado dos impulsos de linguagem, que está sob nossos olhos. A literatura, o fato de traçar letras em uma sequência significativa e importante, é o que é preciso encontrar, se cada um de nós é uma sequência de pensamentos susceptíveis de imprimir-se e de impressionar utilmente. No esforço de traçar sequências de signos pregnantes, busca-se o texto contido, para fazê-lo surgir e mostrá-lo, expô-lo, e oferecê-lo, revelá-lo, se ele conseguir encontrar sua forma. Mas encontra-se o coração da literatura se ele houver encontrado sua forma junto a alguém, que o escreve. A suspensão voluntária da confiança no estado da literatura seguramente permite um rigor no encontro da forma adaptada. Em todo caso, o acesso à linguagem é um acesso às verdades que nela se depositam. ${ }^{32}$ Pode-se sustentar que a literatura é, como a prosa, veículo: acreditamos viver ali em nosso elemento natal, feito de ar,

${ }^{32}$ A Verdade literária é o título de um livro de Marthe Robert (Paris, Grasset, 1981) dedicado a Cervantes, Thomas Mann, Henry James e outros. Pode-se ler o seguinte: "Há em várias produçôes do espírito venenos sutis e violentos, contra os quais não temos nenhum antídoto a não ser um pensamento incessantemente a despertar."
* (VICO. La Science nouvelle (1174), parágrafo 520 (Tradução de Alain Pons. Paris: Fayard, 2011: 241.) 
* (MARCIAL. Epigramas, $X, 2,5$.)

* (REVERDY, Pierre. Le livre de mon bord.) de terra, de fogo e de água, o mangue do espírito, e saber o que ela é, o que ela porta radicalmente. Ora, a prosa elementar, na qual cada um se banha, é também o lugar em que nascem a antipatia, as desafinidades: os átomos eletivos, inclinados, são obtidos na prosa, na qual eles têm uma fé cega, pois nela nascem os pensamentos. Em certa medida, a antipatia se deve à concorrência dos desejos para identificar o porquê e o como da dificuldade de existir no mundo como ele anda (o que Hegel, não sem razão, chama justamente de texto, de prosa do mundo). Sempre, contudo, a aposta de escrever coincide com a aposta singular de ser lido, isto é, ouvido. Lector opes nostrae; quem cum mihi Roma dedisset / Nil tibi quod demus maius habemus, ait. ${ }^{33 *} \mathrm{O}$ concerto das vozes nada mais é do que o concerto dos desejos de fazer ouvir a verdade, a insígnia preocupante, a banda, a sequência dos pensamentos que o mundo torna inevitáveis: é ele quem os semeia na perturbação de cada um. A literatura é a perturbação surgida. Isso resulta em uma guerra expressiva, que é uma guerra fria entre os seres transidos e móveis (capazes de mobilidade). O que dizer desta extraordinária multiplicidade formal, da imensa multidão dos átomos publicantes de agora? Cada um dos átomos ou cada uma das plantas de escrita quer o sucesso, o que não é um crime. A vida de todos os dias prova que o comum desejo de não ter sucesso não logra tornar possível uma comunicação entre os seres. A natureza do sucesso é a única questão. ${ }^{34} \mathrm{Se}$ a publicação é a constituição de um público, então há uma guerra pelo público. Trata-se do sucesso de aceder ao desconhecido, quando se deixou de acreditar que a familiaridade apaga o obstáculo em favor da transparência. "Mas o sucesso carrega tudo. E talvez sejamos mais bem conhecidos e compreendidos assim." $35 *$ Um por todos, todos por um (Unus pro omnibus, omnes pro uno). A solidariedade se apoia no desconhecido e na intempérie. Desconhecidos habitam a mesma noite relativa. "Para se livrar entre nós do fardo do reconhecimento, grita-se de todos os lados: o número dos Au-

33 "Leitor, tu que és toda minha riqueza; pois o dia em que Roma deu-te a mim, ela me disse que não tinha nada melhor a me dar." É a epígrafe do capítulo "O público ocidental e sua linguagem" do magnífico livro póstumo de Erich Auerbach. Op. cit. supra.

${ }^{34}$ A questão do sucesso é uma das principais questôes de Emerson, por exemplo.

${ }^{35}$ Strindberg quer "ter um 'renome'; pois é ele que dá peso ao que se diz!", “ter renome o bastante para que nenhuma dúvida paire sobre [s]eu talento..." (Carta de 4 de maio de 1884, para Bjornstjerne Bjornson). 
tores é imenso." (Louis-Sébastien Mercier $\left.{ }^{36}\right)^{*}$ Buscam-se as razões noturnas dos vapores de Herman Hupfeld (1931): It's still the same old story / A fight for love and glory / A case of do or die. O senso comum (a sabedoria das naçóes) canta em uma fumaça de notas, e se transmuta, arco e lira. Mas segundo o princípio de Reverdy, o amor depende do reconhecimento; o lamento parece deter-se, e o grande público se explica em seu princípio. O desejo de expressão pode ser definido como o desejo de passar firmemente para fora e para um grande público o teor de verdade que habita uma forma humana. Será que a forma humana está aprisionada no desejo de publicidade? Segundo o princípio de Strindberg, ele leva ao cercado simples: "A palavra de ordem de Thomas a Kempis era: 'Tente ficar desconhecido’ Ele quase conseguiu. [...] Inúmeras pessoas menos ilustres padeceram igualmente com esta publicidade que nos trava e nos aplaina. Ela nos trava na medida em que nosso meio nos obriga a desempenhar o papel que escolheu para nós e que ele não permite que modifiquemos. Ao mesmo tempo ela aplaina nossa personalidade ao fazer desaparecer asperezas, finas cinzeladuras, para que nada ultrapasse. Para um ser sensível, o renome torna a vida insuportável. Ele acaba por não sair mais: os olhares das pessoas são como toques, eles penetram em sua carne, palpam-lhe o coração."* $\mathrm{O}$ "olhar das pessoas" suprime então a preciosa diferença entre o conhecido e o desconhecido, sem a qual uma pessoa se transforma em máscara individual fechada. ${ }^{37}$

\footnotetext{
${ }^{36}$ Mercier acrescenta: "Mas de fato, não há na França mais do que trinta Escritores..."

${ }^{37}$ Ver Danilo Martucelli, Grammaires de l'individu. Paris: Gallimard, 2002. Especialmente contra "o emotivismo moral contemporâneo" (: 537), suas descrição dos "estados d'alma", "expressão doravante frequente do desejo de manifestação de uma subjetividade": por meio deles, "exibem-se hesitações, participa-se a profundeza da própria sensibilidade, a fim de melhor tornar-se opaco e inacessível." (ibid.) "Os estados d'alma já são em certos aspectos a expressão mais acabada dos estados subjetivos atuais." (: 539) Eles são ao mesmo tempo "uma expressão do abismo discursivo constitutivo dos indivíduos modernos", um "compromisso entre o crescente reconhecimento das dependências externas e a afirmação de um discurso sobre si cada vez mais independente" e "uma gestão particular da tensão entre as convicções e as ações" (ibid.). O abismo discursivo de agora exige uma descrição mais lenta do que o diagnóstico de logorreia, ao qual Grammaires de l'individu não cede. O ensaio filosófico do livro de Martuccelli é a Grammaire de la multitude de Paolo Virno, de 2001 (Tradução de Véronique Dassas. Paris: L'éclat, 2002). O preâmbulo indica claramente os termos do problema: "Povo versus multidão: Hobbes e Spinoza": "o conceito de multidão, em oposição àquele, mais familiar, de povo, é uma ferramenta decisiva para qualquer reflexão sobre a esfera pública contemporânea. [...] 'Multidão' é o termo perdedor, o conceito
}

* (De la littérature et des littérateurs. op.cit., p. 146147.)

* (Un Livre bleu (1907). Paris: L'Herne, 2006: 189.) 
Entretanto, a generosidade expressiva se alia sutilmente a um desejo de soberania pessoal, um voto de exceção e de isenção em que se dissolve a política. $\mathrm{O}$ escrevente esquece facilmente que a ambição anima o político sem jamais dispensá-lo do interesse geral. A presunção de ser a Insígnia do texto humano é a tentação natural dos particulares. Mas só sou verdadeiramente se o outro me confirma. Quando encontram homens que lhes confirmam a legitimidade da ambição de publicar a banda compartilhada, os escritores podem se espantar, se emocionar. Eles têm razão: a garantia de estar na verdade é paradoxal. Em uma carta a Milena, escrita de Merano em abril-março de 1920, Kafka conta a seguinte história: "A senhora conhece a história do primeiro sucesso de Dostoievski? Ela resume muitas coisas; cito-a, aliás, apenas por comodismo, em razão do grande nome de seu herói, pois poderíamos encontrá-la em outros lugares e até mesmo bem perto de nós. Na verdade, não me lembro muito bem dela, especialmente dos nomes. Dost. escrevia, pois, seu primeiro romance, Gente pobre, e vivia com um amigo, Grigoriev, que também escrevia. Esse Grigoriev viu as páginas se acumularem durante meses sobre a escrivaninha, mas só teve o manuscrito quando o romance havia terminado. Ele o leu, ficou entusiasmado, e o levou, sem nada dizer a D., para o célebre crítico Nekrassov. Na noite seguinte, às três horas da manhã, batem à porta de Dostoievski. São Gr. e N.; eles entram no cômodo, abraçam D., beijam-no, Nekrassov, que o via pela primeira vez, chama-o de esperança da Rússia, eles passam duas horas falando com ele, principalmente sobre o romance, e só o deixam na aurora. D., que sempre chamou essa noite de a mais bela de sua existência, debruça-se então à janela, segue-os com os olhos, não consegue se conter e começa a chorar. O sentimento que dominava então, e que ele descreveu não sei mais onde, era mais ou menos este: 'Que esplêndidas naturezas! Como eles são bons! Com são nobres! E eu, como sou vil! Se eles pudessem ver em mim! E se eu lhes dissesse, não acreditariam em mim!' Nisso, ele quis até alcançá-los por nobreza de alma: mas isso não passa de uma floritura, a última palavra da invencível juventude, isso não faz mais parte da minha história, ela termina aí. Querida Senhora Milena, a senhora observa

que cedeu." (: 7) Seria preciso mostrar - seria o objeto de um ensaio independente - as razões da popularidade do conceito de multidão agora. Virno evoca a "multidão contemporânea". O subtítulo do presente ensaio (Da multidão literária) não evita um termo cuja pertinência geral deve aparecer no exame de uma questão particular na aparência: a expressão. 
o que ela tem de misterioso, de insondável? Isto, creio eu: que Gr. e Nekr., até onde podemos falar dessas coisas em geral, certamente não eram mais nobres do que Dost.; mas renuncie agora ao ponto de vista geral, pelo qual $\mathrm{D}$. também não se interessava naquela noite e que para nada serve no caso particular, veja apenas Dost., e a senhora ficará convencida como ele de que Gr. e N. eram realmente esplêndidos, D. impuro, infinitamente vil, que sempre the será necessária uma distância infinita para um dia igualá-los, por razōes ainda mais fortes ele nunca poderá retribuir-lhes o imenso bem que lhe fizeram, bem imerecido. Vemo-los, literalmente, do alto da janela, afastando-se e significando assim que são inacessíveis. Infelizmente, o sentido da história é apagado pelo grande nome de Dostoievski."

O sentido da história é o seguinte: um escritor impõe uma política - ele fornece elementos à vida comum -, e é por isso que leitores esquecem seu egoísmo afirmativo; eles sabem seu egoísmo afirmativo, e cantam sua gratidão afastando-se dele, enriquecidos pelo esforço do ambicioso, do qual são incapazes. Eles lhe fazem um dom de simpatia, complexo e real, compreensível. Aquele que escreve só, sem eles, adere sozinho à Banda de Moebius que o transe; ele sabe que a gratidão tem tanto sentido quanto a generosidade descritiva de seu livro. Generosidade contra generosidade, uns e o outro se reúnem ao se separarem.

Que a simpatia envolva frequentemente uma antipatia, ou que ela seja a antipatia continuada por outros meios, não impede e até mesmo causa ofato de reconhecimento, que explica a história literária, o tecido de relaçóes descobertas. Rim-ram-rouf, zim-zam-zoum, ${ }^{38}$ a

\footnotetext{
${ }^{38}$ Mandelstam pensa o "balbucio dantesco" como pedagogo da forma do sentido, e respeita a invenção da linguagem acústica ("zum", "para além do espírito", "trans-mental"); ele define Khlebnikov como uma "toupeira" que explora o terreno material do discurso. Mas como o cura dos Contos de Canterbury, pode-se dizer com Chaucer: "Sou do sul, incapaz/ De cantar heróis em rim-ram-ruff." O sonho da glossolalia fechada viveu: o "ganz leere Lirum-larum", o "trá-lá-lá tão vazio" que Hegel estigmatiza no Curso de Estética não é o Gavagai de Quine, e Rabelais, tão consciente da profundidade das massas sonoras, nunca pensou em escrever uma epopeia acústica. $\mathrm{O}$ urso-cantor Colargol entoa uma razoável fatrasia: "Zim-zam-zoum, tric-trac, la Rirette / J'ai pas d'amadou / As-tu ton briquet?" $\mathrm{O}$ fogo ou se presta ou se dá, não pode ser roubado, e esfregar os sons é renunciar a esperar que fagulhas jorrem de um sabão. A propósito de Chaucer, Auerbach constata: "Na base de sua crítica moralizadora encontra-se um instinto para o socialmente desejável, instinto que, se se inspira do cristianismo ou até mesmo da Bíblia, se conforma perfeitamente à experiência direta. Ele nada tem a ver com um programa sistemático teórico-especulativo e desejado por Deus para o mun-
} 
batalha das sílabas juntas hoje, o alarde dos livros, a corte dos milagres de escrita, suas batalhas contínuas, os barouds' (combates rituais profanos, "balas de canhão" lançadas no deserto, pela honra), ou os impulsos rumo à castidade das ideias práticas, são estes também os temas que pretendo tratar neste livro. ${ }^{40}$ Baruffa é a "querela confusa" e o choque, e o verbo alemão bihroufjan significa "gritar todos juntos". Todos gritam juntos na insuficiência do grito, animais de discurso. Caos de agora, uma vez que os humanos apareceram. Como decididamente ver a utilidade de suas divisóes? É preciso gramática, sintaxe, morfologia da multidão em uma terra literária, negra e fecunda, para que a horda segunda, com seus filhosforçados, produza a santa reciprocidade descrita em Hölderlin, a criança "de têmporas grisalhas". Estamos à espera de uma técnica para atravessar as manhãs cinzentas da tolerância que evite a ofuscante realidade do conflito. ${ }^{41}$

A questão é se cada um deve sentir uma "vergonha prometeica" pela literatura: "Vergonha que se apodera do homem diante da humilhante qualidade das coisas que ele próprio fabricou." (Günther Anders.) Pois a literatura é também o reflexo "kafkiano" do mau infinito da guerra, no qual se abisma a filantropia. Uma filogênese das necessidades da literatura seria uma filogênese histórica, bem distinta de uma ontogênese das intensidades divididas.

\section{Tradução de Marcelo Jacques de Moraes (UFRJ)}

do terrestre, como o encontramos em Dante." O que não impede, aliás, Dante de espremer o conteúdo para produzir a plástica sonora de seus versos: "io premerei di mio concetto il suco" (Inferno, XXXII, 4). Para todos, a língua material funda a descoberta de uma verdade.

${ }^{39}$ Palavra árabe, significa pólvora. Em gíria militar, significa um combate de honra, numa guerra perdida. (Nota do tradutor.)

${ }^{40} \mathrm{O}$ artigo em questão é na verdade a introdução do livro do autor, no prelo. Cf. nota 1. (Nota do tradutor.)

${ }^{41}$ Rimbaud, 1873, "Adeus". "É preciso ser absolutamente moderno./ Nada de cânticos: manter o passo ganho. Dura noite! O sangue seco fuma em minha face, e nada tenho atrás de mim, a não ser este arbusto!.../ O combate espiritual é tão brutal quanto a batalha de homens; mas a visão da justiça é o prazer de Deus apenas." Antes de Rimbaud, Jean-Paul havia dito a violência do "combate espiritual": "Uma revolução espiritual e maior que a revolução política, e tão mortífera quanto esta, bate no coração do mundo." Citado por Harry Mulisch em L'Affaire 40/61 (1961). "Arcades". Gallimard, Paris, 2003: 142. 


\section{Philippe Beck}

É poeta, ensaísta e professor de filosofia da Universidade de Nantes. Entre suas principais obras destacam-se: Dernière mode familiale (Flammarion, 2000), Poésies didactiques (Théâtre typographique, 2001), Chants populaires (Flammarion, 2007) e Boustrophes (Texts \& Crafts, 2011), no domínio da poesia, e Beck, l'Impersonnage : rencontre avec Gérard Tessier (Argol, 2006), Un Journal (Flammarion, 2008) e La Berceuse et le Clairon, essai sur la multitude littéraire (Le Bruit du temps, no prelo), no domínio do ensaio.

\section{Resumo}

O artigo introduz o problema da multidão literária de maneira conceitual-polêmica, esboçando uma análise do individualismo expressivo e do elã expressivo que o funda. Sua questão mais importante certamente está ligada ao sentido de nossa ambivalência em relação à escrita. O problema da expressão é o problema do movimento pelo qual cada um se autoriza a formular publicamente o que traz em si, que o atravessa ou trabalha.

\section{Abstract}

The article introduces the problem of literary crowd, in a conceptual-polemical way, outlining an analysis of expressive individualism and the expressive élan that founds it. His most important question probably relates to the meaning of our ambivalence about writing. The problem of expression is the problem of the movement by which each one allows himself to make public what he brings, passing through him or working him.

\section{Résumé}

L'article introduit le problème de la multitude littéraire de façon conceptuelle-polémique, esquissant une analyse de l'individualisme expressif et de l'élan expressif qui le fonde. Sa question la plus importante sans doute concerne le sens de notre ambivalence pour l'écriture. Le problème de l'expression est le problème du mouvement par quoi chacun s'autorise à formuler publiquement ce qu'il porte, qui le traverse ou travaille.
Palavras-chave: individualismo; multidão; expressão; escrita.
Keywords: individualism; crowd; expression; writing.

Mots-clés: individualisme; foule; expression; écriture. 